\title{
Fertilizer Effects on Early Growth and Yield of 'Hamlin' Orange Trees
}

\author{
Thomas A. Obreza' and Robert E. Rouse ${ }^{2}$ \\ Southwest Florida Research and Education Center, University of Florida, \\ P.O. Drawer 5127, Immokalee, FL 33934
}

Additional index words. Citrus sinensis, Carrizo citrange, trifoliate hybrids, fruit quality

Abstract. The growth response of young 'Hamlin' orange (Citrus sinensis L. Osbeck) on Carrizo citrange $(\boldsymbol{C}$. sinensis $\times$ Poncirus trifoliatu L. Raf.) trees to N-P-K fertilizer rates under field conditions in southwestern Florida was studied to determine the minimum fertilizer required to bring trees into maximum early production. The highest $8 \mathrm{~N}-1.8 \mathrm{P}$ $6.6 \mathrm{~K}$ fertilizer rate was $2.72,5.45$, and $8.17 \mathrm{~kg} /$ tree in 1989,1990 , and 1991 , respectively. Additional fertilizer treatments equaled $50 \%, 25 \%$, or $13 \%$ of the maximum rate. Fertilizer sources contained either all water-soluble N (applied more frequently) or $40 \%$ to $50 \%$ controlled-release $\mathrm{N}$ (applied less frequently), and they did not affect fruit yield or quality. The response of trunk cross-sectional area, tree canopy volume, and fruit yield to fertilizer rate was described by a linear plateau model. The model predicted a fruit yield of $22.6 \mathrm{~kg} /$ tree at the estimated critical fertilizer rate of $48 \%$ of maximum. Fruit yield at the $50 \%$ maximum rate averaged $21.2 \mathrm{~kg} /$ tree. As fertilizer rate increased, total soluble solids concentration (TSS) in juice and the TSS : acid ratio decreased, but weight per fruit and TSS per tree increased. A fruit yield $>21 \mathrm{~kg} / 31$-month-old tree indicated vigorous growth.

More than 48,000 ha of new citrus groves has been established in Florida since 1988 (Florida Dept. of Agr. and Consumer Serv., 1990). Land used for citrus production in southwestern Florida increased from 21,000 ha in 1980 to 51,000 ha in 1990 . New plantings are expected to continue through the $1990 \mathrm{~s}$, most in Florida's new citrus-producing region.

The effect of agricultural practices on the environment is a concern associated with this growth. The mobility of $\mathrm{N}$ fertilizer in sandy Florida soils presents the potential for groundwater contamination. Adopting management practices to increase fertilizer efficiency (defined as the proportion of applied fertilizer taken up by the plant) should minimize environmental effects andreduce production costs. An example of such practices is using fertilizer rates near the minimum required by the plant for maximum growth under an application strategy that decreases leaching.

Milder winter temperatures in southwestem Florida allow a longer growing season than in central Florida. To produce large trees quickly and accelerate fruit production, growers have fertilized young trees at rates exceeding current N-P-K recommendations (Koo et al., 1984). These recommendations do not differentiate between central and southern Florida with respect to fertilizer rates.

Most citrus fertilization studies in Florida have involved trees established in the field for

Received for publication 17 Apr. 1992. Accepted for publication 24 Aug. 1992. Florida Agr. Expt. Sta. Journal Series no. R-02315. The cost of publishing this paper was defrayed in part by the bayment of page charges. Under postal regulations, this papertherefore must be hereby marked advertisement solely to indicate this fact.

'Assistant Professor, Soil Scientist.

${ }^{2}$ Associate Professor, Citrus Horticulturist. several years before the experiments were initiated. Research data illustrating the response of newly planted trees to N-P-K fertilizer rates are limited, especially for citrus planted on southern Florida Spodosols and Alfisols. Such data are necessary to make recommendations that maximize fertilizer efficiency

Rasmussen and Smith (1961) conducted one of the earliest comprehensive fertilizer rate studies with newly planted citrus trees in Florida. Satisfactory growth of young 'Hamlin' orange trees was effected by $0.45,0.91$, and $1.82 \mathrm{~kg} /$ tree of an $8 \mathrm{~N}-0.9 \mathrm{P} 6.6 \mathrm{~K}$ fertilizer applied 1, 2, and 3 years after planting, respectively. Calvert (1969) determined that young 'Valencia' orange trees in the Indian River area responded most favorably when 2.72 to $3.63 \mathrm{~kg} /$ tree of an $8 \mathrm{~N}-1.8 \mathrm{P}-6.6 \mathrm{~K}$ fertilizer was applied for three consecutive years. The trees, however, were 2 years old when the experiment was initiated.

Table 1. N-P-K fertilizer treatments applied to young 'Hamlin' orange on Carrizo citrange rootstock trees, 1989-91.

\begin{tabular}{|c|c|c|c|c|c|c|c|c|}
\hline \multirow{2}{*}{$\begin{array}{l}\text { Relative } \\
\text { fertilizer } \\
\text { rate }^{z}(\%)\end{array}$} & \multirow[b]{2}{*}{ Source $y$} & \multirow{2}{*}{$\begin{array}{l}\text { Analysis } \\
(\% \mathrm{~N}-\mathrm{P}-\mathrm{K})\end{array}$} & \multicolumn{3}{|c|}{$\begin{array}{l}\text { Fertilizer annual application rate } \\
\qquad(\mathrm{kg} / \text { tree })\end{array}$} & \multicolumn{3}{|c|}{$\begin{array}{l}\text { 3-yr total application } \\
(\mathrm{kg} / \text { tree })\end{array}$} \\
\hline & & & 1989 & 1990 & 1991 & $\bar{N}$ & $P$ & $\mathrm{~K}$ \\
\hline 13 & $\mathrm{CONV}$ & $8-1.8-6.6$ & 0.34 & 0.68 & 1.02 & 0.16 & 0.04 & 0.14 \\
\hline 25 & & & 0.68 & 1.36 & 2.04 & 0.33 & 0.07 & 0.27 \\
\hline 50 & & & 1.36 & 2.72 & 4.09 & 0.65 & 0.15 & 0.54 \\
\hline 100 & & & 2.72 & 5.45 & 8.17 & 1.31 & 0.29 & 1.08 \\
\hline 13 & IBDU & $8-1.8-6.6$ & 0.34 & 0.68 & 1.02 & 0.16 & 0.04 & 0.14 \\
\hline 25 & & & 0.68 & 1.36 & 2.04 & 0.33 & 0.07 & 0.27 \\
\hline 50 & & & 1.36 & 2.72 & 4.09 & 0.65 & 0.15 & 0.54 \\
\hline 100 & & & 2.72 & 5.45 & 8.17 & 1.31 & 0.29 & 1.08 \\
\hline 13 & MU & $9-2.2-6.6$ & 0.30 & 0.61 & 0.91 & 0.16 & 0.04 & 0.12 \\
\hline 25 & & & 0.61 & 1.21 & 1.82 & 0.33 & 0.08 & 0.24 \\
\hline 50 & & & 1.21 & 2.42 & 3.63 & 0.65 & 0.16 & 0.48 \\
\hline 100 & & & 2.42 & 4.85 & 7.27 & 1.31 & 0.32 & 0.96 \\
\hline
\end{tabular}

${ }^{2}$ Percentage of maximum rate applied.

${ }^{y} \mathrm{CONV}=$ all water-soluble $\mathrm{N} ; \mathrm{IBDU}=$ controlled-release $\mathrm{N}$ as isobutylidene diurea; $\mathrm{MU}=$ controlledrelease $\mathrm{N}$ as methylene urea.
Recent studies withnewly planted 'Hamlin' orange trees in several Florida locations have suggested that the current fertilizer recommendation for the first year $(2.0$ to $3.4 \mathrm{~kg} /$ tree of $8 \mathrm{~N}-3.5 \mathrm{P}-6.6 \mathrm{~K}$ fertilizer) may exceed that required for maximum growth. Ferguson et al.'s (1988) experiments with newly planted 'Hamlin' orange trees in central and eastcoastal Florida showed that $\mathrm{N}$ fertilizer applied at $26 \%$ to $60 \%$ of the recommended rate failed to affect trunk diameter in the first year. Marler et al. (1987) studied first-year growth of newly planted trees on an acidic Ultisol in north-central Florida and found no trunk crosssectional area (TCA) or canopy volume differences between $0.91,1.82$, or $2.72 \mathrm{~kg} /$ tree of an $8 \mathrm{~N}-2.6 \mathrm{P}-6.6 \mathrm{~K}$ fertilizer. However, Willis et al. (1990), working in the same area, observed a positive linear response of 'Hamlin' orange trunk diameter to $8 \mathrm{~N}-0 \mathrm{P}-6.6 \mathrm{~K}$ fertilizer rates of $0.75,1.38$, and $2.88 \mathrm{~kg} /$ tree applied 8 months after planting.

Research with young trees in more northem Florida locations has involved a series of single-ye\& studies that could not be continued due to winter freezes. This study was designed to determine the minimum N-P-K fertilizer required to produce fruit on young 'Hamlin' orange trees in southwestern Florida. The objective was to determine the relationship between N-P-K fertilizer rates and young 'Hamlin' orange tree growth, leaf tissue nutrient concentration, early fruit yield, and fruit quality.

This experiment was conducted within a large, newly developed commercial Florida citrus grove. The site was similar to most new groves in the region in terms of soil type (Spodosols and Alfisols) and previous land use (range land for cattle). Land that had been in unimproved pasture for $>25$ years was disked, laser-leveled, and formed into tworow beds during Summer and Fall 1988. 'Hamlin' orange on Carrizo citrange trees were planted in Mar. 1989 at a 2.7-m (within rows) $x$ 7.6-m (between rows) spacing. The trees were subirrigated, with water supplied through upward flux from a water table maintained $\approx 0.60$ to $0.75 \mathrm{~m}$ below the soil surface. 
The experiment was conducted within four adjacent tree rows (two two-row beds). The soils were classified as Pople fine sand (loamy, siliceous, hyperthermic Arenic Ochraqualf) and Holopaw sand (loamy, siliceous, hyperthermic Grossarenic Ochraqualf). The area was divided into eight blocks (replications), and plots within each blockconsisted of four adjacent trees within a row. One replication of each fertilizer treatment was randomly assigned to a plot within each block. Treatments consisted of three N-P-K fertilizers-one containing all water-soluble $\mathrm{N}$ and the others containing a portion of the $\mathrm{N}$ in controlledrelease form-applied at four rates (Table 1). A nonfertilized control was also included.

The maximum $8 \mathrm{~N}-1.8 \mathrm{P}-6.6 \mathrm{~K}$ fertilizer rate was $2.72,5.45$, and $8.17 \mathrm{~kg} /$ tree in 1989,1990 , and 1991, respectively. These rates are $\approx 10 \%$ higher than the current average N-P-K recommendation for Florida citrus trees in each of the first 3 years after planting (Koo et al., 1984). Additional fertilizer treatments equaled $50 \%, 25 \%$, or $13 \%$ of the maximum rate each year.

The conventional (CONV) fertilizer source contained all water-soluble $\mathrm{N}$ (as $\mathrm{NH}_{4}$ and $\mathrm{NO}_{3}$ ), $3.0 \% \mathrm{Mg}, 0.3 \% \mathrm{Mn}$, and $0.05 \% \mathrm{Fe}$. In addition to $2.4 \% \mathrm{Mg}, 0.3 \% \mathrm{Mn}$, and $0.06 \% \mathrm{Fe}$, the second source contained $50 \%$ water-soluble $\mathrm{N}$ (as $\mathrm{NH}_{4}$ and $\mathrm{NO}_{3}$ ) and $50 \% \mathrm{~N}$ as controlledrelease isobutylidene diurea (IBDU). The third source contained $60 \%$ water-soluble $\mathrm{N}$ (as urea, $\mathrm{NH}_{4}$, and $\mathrm{NO}_{3}$ ) and $40 \%$ controlled-release $\mathrm{N}$, including methylene urea (MU), sulfur-coated urea, and activated sludge, with $3.0 \% \mathrm{Mg}, 0.5 \% \mathrm{Mn}$, and $0.03 \% \mathrm{Fe}$. Phosphorus was applied as monocalcium phosphate, $\mathrm{K}$ as potassium sulfate, $\mathrm{Mg}$ as magnesium sulfate, $\mathrm{Mn}$ as manganese sulfate or manganese oxide, and $\mathrm{Fe}$ as iron-EDTA.

Following tree planting, soil samples were collected from each block and initial trunk diameter measured. The diameter of the two middle trees in each four-tree plot was measured $15 \mathrm{~cm}$ above the bud union in northsouth and east-west directions. Assuming a circular trunk, the TCA was calculated from the mean radius.

Initial fertilizer applications were made in Apr. 1989. The fertilizer materials were applied by hand under the trees in a $1-\mathrm{m}$ circle at first and later in a wider circle that matched tree canopy expansion as the trees grew. The CONV fertilizer was split equally into six applications in 1989 (April, June, July, September, October, December), five in 1990 (March, May, July, September, November), and four in 1991 (March, May, July, November). The IBDU fertilizer was split equally into three applications in 1989 (April, July, November), three in 1990 (March, June, September), and two in 1991 (March, August). The MU fertilizer was split equally into two applications each in 1989 (April, September), 1990, and 1991 (both years March, August).

TCA was calculated at 7,12, and 24 months after planting. Mean canopy width (measured in north-south and east-west directions) and height were measured at 12 and 24 months after planting. The height was greater than the width, so canopy volume was calculated based on the formula for a prolate spheroid shape: (4/ $3)(\pi)\left(\right.$ tree height/2)(mean canopy radius) ${ }^{2}$.

Leaf tissue samples from 5- to 6-monthold autumn growth were taken from each plot in mid-Mar. 1990 and 1991, marking the conclusion of one fertilizer year and the beginning of the next. Samples were dried and ground to pass a 1-mm screen, and 1-g subsamples were ashed in a muffle furnace at 500C. The residue was dissolved in concentrated $\mathrm{HC} 1$, and the resulting solution was analyzed for $\mathrm{K}, \mathrm{Ca}$, and $\mathrm{Mg}$ concentration using atomic emission/absorption spectrophotometry (Baker and Suhr, 1982), and for P concentration using the ascorbic acid method (Council on Soil Testing and Plant Analysis, 1980). A 0.4-g subsample of the ground tissue was digested in concentrated $\mathrm{H}_{2} \mathrm{SO}_{4}$, and the resultant solution was analyzed for $\mathrm{N}$ concentration using the indophenol blue method (Hanlon and DeVore, 1989).

Soil core samples, $2 \mathrm{~cm}$ in diameter, were taken to a $15-\mathrm{cm}$ depth at the tree drip line at planting. The soil was air-dried and passed through a 1-mm screen. A 5-g subsample was extracted with $20 \mathrm{ml}$ of Mehlich 1 solution $\left(0.05\right.$ м HC1 $\left.+0.0125 \mathrm{M} \mathrm{H}_{2} \mathrm{SO}_{4}\right)$, and the $\mathrm{P}, \mathrm{K}$, $\mathrm{Ca}$, and $\mathrm{Mg}$ concentrations were measured using the methods mentioned above. The soil was also analyzed for $\mathrm{pH}$ ( 2 water : 1 soil ratio) and Walkley-Black organic matter content (Hanlon and DeVore, 1989).

Fruit yield was determined in Oct. 1991 (31 months after planting). Fruit on the middle two trees in each plot was harvested and weighed. A random 40-fruit subsample from each plot was used to estimate size and analyze juice quality. The juice was extracted using a commercial juice extractor (FMC Corp., Jonesboro, Ark.). Juice quality characteristics included percent juice per fruit, total soluble

Table 2. Selected soil characteristics of the experimental site (data represent the mean of eight samples taken at planting in 1989).

\begin{tabular}{|c|c|c|c|c|c|c|c|}
\hline \multirow{2}{*}{$\begin{array}{l}\text { Depth } \\
(\mathrm{cm})\end{array}$} & \multirow[b]{2}{*}{ Texture } & \multirow[b]{2}{*}{$\mathrm{pH}$} & \multirow{2}{*}{$\begin{array}{c}\text { Organic } \\
\text { matter } \\
(\%)\end{array}$} & \multicolumn{4}{|c|}{$\begin{array}{c}\text { Mehlich } \\
\text { 1-extractable } \\
\left(\mathrm{mg}^{\mathrm{kg}} \mathrm{k}^{-1}\right)\end{array}$} \\
\hline & & & & $\mathbf{P}$ & $\mathrm{K}$ & $\mathrm{Ca}$ & $\mathrm{Mg}$ \\
\hline $0-15$ & Sand & 7.0 & 1.0 & 8 & 7 & 1160 & 20 \\
\hline $15-30$ & Sand & 5.3 & 1.4 & 5 & 5 & 570 & 14 \\
\hline
\end{tabular}

solids concentration (TSS), acid content, and TSS : acid ratio. Per-tree TSS was calculated from yield, percent juice, and juice TSS.

Analysis of variance and linear or nonlinear regression were used to determine main effects and fertilizer source $\times$ rate interaction on tree growth and yield variables and leaf nutrient concentrations. Relative fruit yield, canopy volume, and TCA values were calculated by: relative yield $=100 \times($ actual yield $) /($ highest yield). A linear plateau function was fitted to the data (pooled across fertilizer sources due to lack of interaction) relating the relative growth or yield variables to fertilizer rate: yield $=\mathrm{A}+\mathrm{B}(\mathrm{X})$ (when $\mathrm{X}$ is below the critica rate); yield $=A+B(C R)$ (when $X$ is above the critical rate), where $X=$ relative fertilizer rate and $\mathrm{CR}=$ critical fertilizer rate (the point at which maximum yield is reached). Duncan's multiple range test was used to evaluate the effect of fertilizer source at each rate. The response of leaf nutrient concentration was examined with respect to fertilizer rates across all sources.

The soil in which the trees were planted had not been previously fertilized and was very low in extractable $\mathrm{P}$ and $\mathrm{K}$ at planting (Table 2). The organic matter content was higher in the $15-$ to $30-\mathrm{cm}$ soil depth than in the top $15 \mathrm{~cm}$, because the original pasture surface layer was buried under the subsurface material used to form the planted beds. The $\mathrm{pH}$ of the bed surface soil was considerably higher than that of the original surface (Table 2); however, roots of the citrus trees were exposed to both soils during planting, since the plant holes were $\mathrm{dug} \approx 30 \mathrm{~cm}$ deep.

During the second and third years of tree growth, fertilizer source had no effect on any growth, yield, or fruit quality response variables measured. There was no interaction between fertilizer source and rate. Rainfall in 1990 was $20 \%$ below normal (127 cm annually) but was $20 \%$ above normal in 1991 . CONV source efficiency was likely increased through higher application frequency. The remaining discussion deals with the response of growth/yield/quality variables to fertilizer rate across sources.

There was no response of TCA to fertilizer rate at 7 months after planting (Table 3). About $60 \%$ of the total first-year trunk growth occurred between Oct. 1989 and Mar. 1990 (7

Table 3. Growth and yieldresponse of young 'Hamlin' orange on Carrizo citrange rootstock trees to fertilizer rates through the first 31 months after planting. Values in parentheses represent the percentage of the maximum value for the variable.

\begin{tabular}{|c|c|c|c|c|c|c|c|}
\hline \multirow{3}{*}{$\begin{array}{l}\text { Relative } \\
\text { fertilizer } \\
\text { rate }^{y}\end{array}$} & \multicolumn{4}{|c|}{$\mathrm{TCA}^{\mathrm{z}}\left(\mathrm{cm}^{2}\right)$} & \multicolumn{2}{|c|}{ Canopy vol $\left(\mathrm{m}^{3}\right)$} & \multirow[t]{2}{*}{$\begin{array}{l}\text { Fruit yield } \\
(\mathrm{kg} / \text { tree })\end{array}$} \\
\hline & \multicolumn{6}{|c|}{ Months after planting } & \\
\hline & 0 & 7 & 12 & 24 & 12 & 24 & 31 \\
\hline$\overline{0}$ & 1.4 & $3.4(88)$ & $6.2(79)$ & $28.1(75)$ & $0.8(65)$ & $5.8(59)$ & $2.0(8)$ \\
\hline 13 & 1.4 & $3.5(91)$ & $6.6(84)$ & $31.6(85)$ & $1.0(78)$ & $7.8(80)$ & $6.1(26)$ \\
\hline 25 & 1.4 & $3.7(97)$ & $7.3(93)$ & $34.4(92)$ & $1.1(88)$ & $8.4(85)$ & $12.7(53)$ \\
\hline 50 & 1.4 & $3.8(100)$ & $7.8(100)$ & $37.2(100)$ & $1.3(100)$ & $9.8(100)$ & $21.2(89)$ \\
\hline 100 & 1.4 & $3.6(94)$ & $6.9(89)$ & $33.8(91)$ & $1.2(90)$ & $8.9(90)$ & $23.9(100)$ \\
\hline \multicolumn{8}{|l|}{ Significance } \\
\hline Linear-plateau & NS & NS & $* *$ & $* *$ & $* *$ & $* *$ & $* *$ \\
\hline
\end{tabular}

zTCA = trunk cross-sectional area.

yercentage of maximum rate applied.

Ns, **Nonsignificant or significant at $P=0.01$, respectively. 
to 12 months after planting). Above-normal temperatures were most likely a contributing factor to the substantial growth observed during fall and winter, traditionally a "dormant" period for citrus trees in Florida.

At 12 and 24 months, TCA and canopy volume response to fertilizer rate was described by a linear plateau model (Table 3,Fig. 1). The model estimated a critical fertilizer rate-at whichmaximum growth was reached-of $30 \%$ and $33 \%$ of maximum for TCA and canopy volume, respectively. Largest trunk and canopy size was observed at the $50 \%$ rate. The decrease in these variables at the $100 \%$ rate may have been due to applying the fertilizers by hand. The materials may have been too concentrated around the trees during the first year, and the high soil salt levels from the $100 \%$ rate could have retarded tree growth.

The response of fruit yield to fertilizer rate was described by a linear-plateau model (Table 3, Fig. 1). The model predicted a fruit yield of $22.6 \mathrm{~kg} /$ tree at an estimated critical rate of $48 \%$-a value in good agreement with the observed yield of $21.2 \mathrm{~kg} /$ tree at the $50 \%$ rate.

Trees receiving the $100 \%$ rate yielded $11 \%$ more fruit, with $10 \%$ less canopy volume (at 24 months), than trees receiving the $50 \%$ rate. However, tree canopy volume at 24 months and fruit yield at 31 months were poorly correlated ( $r=0.45)$. Nonfertilized tree canopy volume was $59 \%$ of observed maximum, but yield was only $8 \%$ of maximum. Tree canopy volume in the spring of the first bearing year was not a good predictor of yield in this experiment.

Weight per fruit increased linearly with fertilizer rate (Table 4). Mean fruit diameter was estimated from fruit weight of fruit subsamples by the regression equation: fruit

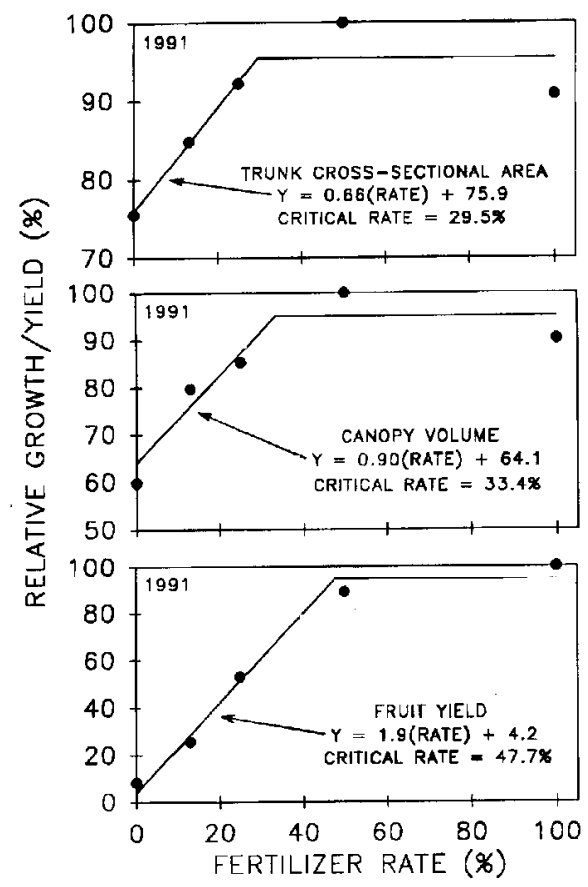

Fig. 1. Relative growth and yield response of young 'Hamlin' orange on Carrizo citrange rootstock trees to fertilizer rate.

Table 4. Fruit quality response of young 'Hamlin' orange on Carrizo citrange rootstock trees to fertilizer rate, 1991.

\begin{tabular}{|c|c|c|c|c|c|c|}
\hline $\begin{array}{l}\text { Relative } \\
\text { fertilizer } \\
\text { rate }^{z}(\%)\end{array}$ & $\begin{array}{c}\text { Wt/fruit } \\
(\mathrm{kg})\end{array}$ & $\begin{array}{c}\text { Juice } \\
\text { concn } \\
(\%)\end{array}$ & $\begin{array}{c}\text { TSS }^{y} \\
(\%)\end{array}$ & $\begin{array}{c}\text { Acid } \\
(\%)\end{array}$ & $\begin{array}{c}\text { TSS : acid } \\
\text { ratio } \\
\end{array}$ & $\begin{array}{c}\text { TSS/tree } \\
(\mathrm{kg})\end{array}$ \\
\hline 0 & 0.14 & 54.9 & 8.4 & 0.39 & 21.7 & 0.09 \\
\hline 13 & 0.16 & 53.8 & 7.9 & 0.50 & 16.9 & 0.26 \\
\hline 25 & 0.17 & 49.8 & 7.6 & 0.47 & 16.6 & 0.48 \\
\hline 50 & 0.17 & 52.8 & 7.5 & 0.51 & 14.9 & 0.84 \\
\hline 100 & 0.18 & 53.6 & 7.4 & 0.54 & 13.9 & 0.95 \\
\hline \multicolumn{7}{|l|}{ Significance } \\
\hline $\begin{array}{l}\text { Linear } \\
\text { Exponential }\end{array}$ & $* *$ & NS & $* *$ & NS & $* *$ & $* *$ \\
\hline
\end{tabular}

${ }^{z}$ TSS $=$ total soluble solids concentration.

yPercentage of maximum rate applied.

ss, ** Nonsignificant or significant at $P=0.01$, respectively.

Table 5. Leaf tissue nutrient concentration response of young 'Hamlin' orange on Carrizo citrange rootstock trees to fertilizer rate.

\begin{tabular}{|c|c|c|c|c|c|}
\hline $\begin{array}{l}\text { Relative } \\
\text { fertilizer } \\
\text { rate }^{z}(\%)\end{array}$ & $\begin{array}{c}\mathrm{N} \\
(\%)\end{array}$ & $\underset{(\%)}{P}$ & $\begin{array}{c}\mathrm{K} \\
(\%)\end{array}$ & $\begin{array}{c}\mathrm{Ca} \\
(\%)\end{array}$ & $\begin{array}{l}\mathrm{Mg} \\
(\%)\end{array}$ \\
\hline \multicolumn{6}{|c|}{1990} \\
\hline 0 & 3.19 & 0.18 & 1.68 & 2.88 & 0.30 \\
\hline 13 & 3.11 & 0.15 & 1.72 & 2.78 & 0.24 \\
\hline 25 & 3.10 & 0.15 & 1.98 & 2.61 & 0.23 \\
\hline 50 & 3.17 & 0.16 & 2.27 & 2.47 & 0.25 \\
\hline 100 & 3.38 & 0.15 & 2.61 & 2.21 & 0.26 \\
\hline \multicolumn{6}{|l|}{ Significance } \\
\hline Linear & $*$ & NS & $* *$ & $*$ & NS \\
\hline \multicolumn{6}{|c|}{1991} \\
\hline 0 & 2.78 & 0.16 & 1.61 & 4.65 & 0.32 \\
\hline 13 & 2.61 & 0.16 & 1.51 & 4.76 & 0.30 \\
\hline 25 & 2.74 & 0.16 & 1.83 & 4.35 & 0.30 \\
\hline 50 & 2.90 & 0.16 & 2.29 & 4.27 & 0.33 \\
\hline 100 & 2.89 & 0.16 & 2.62 & 4.01 & 0.34 \\
\hline \multicolumn{6}{|l|}{ Significance } \\
\hline Linear & $*$ & NS & $* *$ & $* *$ & NS \\
\hline
\end{tabular}

${ }^{2}$ Percentage of maximum rate applied.

ws, *, ** Nonsignificant or significant at $P=0.05$ or 0.01 , respectively.

diameter $=0.0145$ (fruit weight) $+4.51, r^{2}=$ 0.97. Fruit from nonfertilized trees averaged $6.48 \mathrm{~cm}$ in diameter and were classified as no. 125 commercial size for Florida oranges (fruit diameter range 6.35-6.99 $\mathrm{cm}$ ). Fruit from fertilized trees averaged $6.97 \mathrm{~cm}$ in diameter and were classified as no. 100 commercial size (fruit diameter range $6.83-7.62 \mathrm{~cm}$ ). Commercial sizes are based on the number of fruit that fit in a 92-liter carton; thus, the lower the commercial size number, the larger the fruit.

TSS and the TSS : acid ratio decreased linearly with increasing fertilizer rate. The decrease in ratio was due solely to decreasing TSS; acid concentration did not vary significantly with fertilizer rate. Juice concentration per fruit was also unaffected by fertilizer rate. TSS per tree increased exponentially with fertilizer rate.

Leaf tissue concentrations of $\mathrm{N}$ and $\mathrm{K}$ increased linearly with fertilizer rate in 1990 and 1991 (Table 5). Leaf Ca decreased linearly as fertilizer rate increased both years, which may have been due to the competitive effects of increasing the soil K level (Barber, 1984). Both leaf $\mathrm{P}$ and $\mathrm{Mg}$ levels were unaffected by fertilizer rate. This result was unexpected for $\mathrm{P}$, considering the low extractable-P levels in the nonfertilized soil. Compared with leaf analysis standards for 4- to 6-month-old spring growth (Koo et al., 1984), the N, P, and K concentrations of the 6-month-old fall leaves were optimum or high in both years, regardless of fertilizer rate. The $\mathrm{Ca}$ and $\mathrm{Mg}$ concentrations were low in 1990 but optimum in 1991.

Leaf $\mathrm{N}$ concentration was $\approx 0.4 \%$ higher across all treatments in 1990 than in 1991 (Table 5). For citrus nursery trees in Florida, elevated levels of nutrients stored in tissues have been attributed to intensive fertilization in the nursery (Castleand Rouse, 1990) Higher leaf $\mathrm{N}$ levels in the 12-month-old trees may have been due to a carryover effect from high $\mathrm{N}$ levels in the trees at planting.

This experiment's results show that maximum growth and early yield of 'Hamlin' orange trees planted on a typical southwestern Florida flatwoods soil can be obtained by applying N-P-K fertilizer at $50 \%$ of the currently recommended rate. This agrees with the findings of Marler et al. (1987) and Ferguson et al. (1988). A yield of 21 to $24 \mathrm{~kg}$ fruit/tree for trees planted slightly $>2.5$ years indicates vigorous growth. Criticalrates for TCA, canopy volume, and fruit yield as estimated by a linear-plateau model were $\leq 50 \%$. Fertilizing to, but not in excess of, the critical rate is logical economically and should provide the highest fertilizer efficiency. Using higher rates 
because of the longer growing season in southwestern Florida is not justified.

Using fertilizer rates below the critical rate may be advantageous if fruit is to be grown for the early fresh market. Even though yield decreased, 'Hamlin' orange maturity based on TSS and TSS : acid ratio was more advanced at lower fertilization rates. Fruit size decreased only slightly at lower fertilizer rates.

Measuring canopy volume may not be meaningful for young citrus trees, because canopy density can vary among trees with similar canopy volume. Measuring canopy density could possibly produce a higher correlation with fruit yield of young trees.

Leaftissue analysis data (from fall growth) were compared with leaf analysis standards as defined by Koo et al. (1984). These standards are based on established criteria derived from spring growth and are directly related to productivity. Leaf $\mathrm{N}, \mathrm{P}, \mathrm{K}, \mathrm{Ca}$, and $\mathrm{Mg}$ concentrations from trees receiving fertilizer rates that limited yield were optimum or high in the first bearing year. These results were not indicative of tree size or early fruit yield. Willis et al.
(1990) also observed this phenomenon. Acceptable ranges for leaf nutrient concentrations have been developed from data obtained from mature trees and apparently should not be used to evaluate the nutritional status of vigorously growing young trees.

\section{Literature Cited}

Baker, D.E. and N.H. Suhr. 1982. Atomic absorption and flame emission spectrophotometry, $\mathrm{p}$. 13-27. In: A.L. Page (ed.). Methods of soil analysis, part 2. Amer. Soc. of Agron., Madison, Wis.

Barber, S.A. 1984. Soil nutrient bioavailability. Wiley, New York.

Calvert, D.V. 1969. Effects of rate and frequency of fertilizer applications on growth, yield and quality factors of young 'Valencia' orange trees. Proc. Fla. State Hort. Soc. 82:1-7.

Castle, W.S. and R.E. Rouse. 1990. Total mineral nutrient content of Florida citrus nursery plants Proc. Fla. State Hort. Soc. 103:42-44.

Council on Soil Testing and Plant Analysis. 1980. Handbook on reference methods for soil testing. revised ed. Council Soil Testing Plant Analysis, Athens, Ga.
Ferguson, J.J., F.S. Davies, C.H. Matthews, and R.M. Davis. 1988. Controlled-release fertilizers and growth of young 'Hamlin' orange trees. Proc. Fla. State Hort. Soc. 101:17-20.

Florida Dept. of Agriculture and Consumer Services. 1990. Commercial citrus inventory. Florida Agr. Stat. Serv., Orlando.

Hanlon, E.A. and J.M. DeVore. 1989. IFAS extension soil testing laboratory chemical procedures and training manual. Florida Coop. Ext. Serv. Circ. 812, Univ. of Florida, Gainesville.

Koo, R.C.J., C.A. Anderson, I. Stewart, D.P.H Tucker, D.V. Calvert and H.K. Wutscher. 1984. Recommended fertilizers and nutritional sprays for citrus. Florida Agr. Expt. Sta. Bul. 536D Univ. of Florida, Gainesville.

Marler, T.E., J.J. Ferguson, and F.S. Davies. 1987 Growth of young 'Hamlin' orange trees using standard and controlled-release fertilizers. Proc. Fla. State Hort. Soc. 100:61-64.

Rasmussen, G.K. and P.F. Smith. 1961. Evaluation of fertilizer practices for young citrus trees. Proc. Fla. State Hort. Soc. 74:90-95.

Willis, L.E., F.S. Davies, and D.A. Graetz. 1990. Fertilization, nitrogen leaching and growth of young 'Hamlin' orange trees on two rootstocks. Proc. Fla. State Hort. Soc. 103:30-37. 